\title{
MENAKAR POTENSI DAN TATANGAN DALAM MENGGAGAS TRANSMIGRASI LOKAL DI DAERAH ISTIMEWA YOGYAKARTA
}

\author{
Pandhu Yuanjaya \\ Fakultas Ilmu Sosial, Universitas Negeri Yogyakarta dan Pusat Studi Kependudukan dan \\ Kebijakan, Universitas Gadjah Mada, pandhu@uny.ac.id
}

\section{Muhammad Arif Fahrudin Alfana}

Fakultas Geografi, Universitas Gadjah Mada dan Pusat Studi Kependudukan dan Kebijakan, Universitas Gadjah Mada, arif.fahrudin@geo.ugm.ac.id

\begin{abstract}
Abstrak
Penelitian ini bertujuan untuk mengkaji potensi dan tantangan transmigrasi lokal di Daerah Istimewa Yogyakarta. Hal ini penting mengingat konsentrasi penduduk terpusat di Kota Yogyakarta dan Kabupaten Sleman sebagai daerah yang lebih maju dari yang lain. Penelitian ini merupakan penelitian kuantitaif dan kualitatif. Data dikumpulkan dengan kuesioner, observasi, wawancara dan telaah data sekunder. Penelitian ini fokus pada Sultan Ground (SG) dan Pakualaman Ground (PAG) di tiga kabupaten, Kabupaten Gunung Kidul, Kabupaten Bantul dan Kabupaten Kulon Progo. Temuan penelitian menunjukkan SG dan PAG potensial dan layak menjadi daerah tujuan transmigrasi lokal. Pemanfaatan lahan di tiga kabupaten dapat bervariasi seperti: pertanian, perkebunan dan perikanan. Beberapa tantangan yang harus diselesaikan sebelum kebijakan ini dilakukan diantaranya penyelesaian status dan konflik penggunaan lahan, penerimaan penduduk lokal dan peningkatan kapasitas transmigran.
\end{abstract}

Kata Kunci: Transmigrasi Lokal, Potensi Daerah, Sultan Ground dan Pakualaman Ground

\begin{abstract}
This study aims to analyze the potentials and challenges of local transmigration in Yogyakarta Special Region. This study crucial to consider the population that is concentrated in the Yogyakarta City and Sleman Regency as areas more develop than others. This is mix method research. Data were collected by questionnaires, observations, interviews and secondary data analysis. This study focused on Sultan Ground (SG) and Pakualaman Ground (PAG) in the three regencys, Gunung Kidul, Bantul and Kulon Progo. The findings show that the SG and PAG, potential and worthy of being local transmigration destination areas. Land use in three districts varied such as: agriculture, farming and fisheries. Some of the challenges that must be resolved before this policy made include the completion status and land-use conflicts, acceptance of local residents and increase the skills capacity of migrants.
\end{abstract}

Keywords: local transmigration, Sultan Ground and Pakualaman Ground.

\section{PENDAHULUAN}

Menggagas transmigrasi sebagai kebijakan penataan persebaran penduduk dan peningkatan pembangunan regional bukanlah ide baru. Pemerintah dan masyarakat Indonesia cukup familiar karena program transmigrasi telah dikenal pada masa pemerintah kolonial Belanda yang tetap dipraktekkan setelah kemerdekaan (Smith,1981; Adhiati dan Bobsien, 2001; Nitiyasa dan Sudibia, 2013). Kondisi persebaran penduduk yang masih sangat timpang antara Jawa-luar Jawa, desa-kota, daerah perbatasan-non perbatasan, program transmigrasi masih sangat relevan dilakukan untuk mengurangi ketimpangan yang terjadi (Hayashida, 2006). Terlebih lagi, paradigma desentralisasi membawa perubahan tata kelola dan sistem pemerintahan yang berimplikasi pada diperlukannya arah baru kebijakan transmigrasi.

Dalam paradigma desentralisasi, pola mobilitas penduduk di masa mendatang akan mengalami perubahan sejalan dengan tingkat perkembangan sosial ekonomi tiap- tiap daerah. Daerah-daerah yang kaya sumber daya, baik sumber daya alam dan sumber daya manusia, diperkirakan akan menjadi daerah pertumbuhan baru yang mampu menarik penduduk untuk berpindah. Provinsi dengan IPM dan PDRB tinggi seperti DKI Jakarta, Kalimantan Timur, DIY, Riau, Kalimantan Tengah, dan Kepulauan Riau, diperkirakan akan menjadi tujuan pencari kerja (lihat Tabel 1). Tentu mobilisasi penduduk ke kota dan daerah berkembang lainnya akan menimbulkan masalah baru yang mungkin terjadi.

Tabel 1. Potensi Daerah Tujuan Mobilitas Penduduk dan

\begin{tabular}{|l|c|c|c|c|c|c|c|c|}
\multicolumn{10}{|c|}{ IPM } \\
\hline \multirow{3}{*}{ Provinsi } & \multicolumn{2}{|c|}{2009} & \multicolumn{2}{c|}{2010} & \multicolumn{2}{|c|}{2011} & \multicolumn{2}{c|}{2012} \\
\cline { 2 - 10 } & IPM & Ranking & IPM & Ranking & IPM & Ranking & IPM & Ranking \\
\hline Riau & 75,68 & 3 & 76,07 & 3 & 76,53 & 3 & 76,90 & 3 \\
\hline Kepulauan Riau & 74,54 & 6 & 75,07 & 6 & 75,78 & 6 & 76,20 & 6 \\
\hline DKI Jakarta & 77,36 & 1 & 77,60 & 1 & 77,97 & 1 & 78,33 & 1 \\
\hline Yogyakarta & 75,23 & 4 & 75,77 & 4 & 76,32 & 4 & 76,75 & 4 \\
\hline $\begin{array}{l}\text { Kalimantan } \\
\text { Tengah }\end{array}$ & 74,36 & 7 & 74,64 & 7 & 75,06 & 7 & 75,46 & 7 \\
\hline $\begin{array}{l}\text { Sulawesi } \\
\text { Tenggara }\end{array}$ & 69,52 & 25 & 70,00 & 25 & 70,55 & 25 & 71,05 & 26 \\
\hline Sulawesi Utara & 75,68 & 2 & 76,09 & 2 & 76,54 & 2 & 76,95 & 2 \\
\hline Indonesia & 70,59 & & 71,17 & & 71,76 & & 72,27 & \\
\hline
\end{tabular}

Sumber: BPS (2013) 
Program transmigrasi kehilangan dukungan politik di daerah. Alasannya, transmigran tidak lagi dianggap sebagai cara meningkatkan pembangunan daerah, kebijakan seharusnya diarahkan pada peningkatan kapasitas masyarakat dan bantuan sosial (Adhiati dan Bobsien, 2001). Pona (2005) mengatakan bahwa transmigrasi menempatkan masyarakat lokal dan pendatang (transmigran) pada posisi yang tidak seimbang dalam kompetisi. Transmigran yang biasanya lebih ahli dan dipersiapkan dalam pengelolaan lahan, umumnya menguasai sektor ekonomi dan sosial sehingga masyarakat lokal tersaingi dan tergeser cukup jauh (Levang et al, 1999; Sheil et al., 2006). Akibatnya, berbagai konflik pada akhirnya muncul sebagai akibat dari ketiadaan perhatian pada hal-hal tersebut (Hugo, 2000; Nugroho, 2013). Disisi lain, berdasarkan data kepadatan penduduk, DKI Jakarta masih menempati provinsi dengan penduduk terpadat $15.173 \mathrm{jiwa} / \mathrm{km}^{2}$, sedangkan yang terendah di Papua Barat 9 jiwa $/ \mathrm{km}^{2}$, terlebih lagi proyeksi tempat tinggal penduduk $50 \%$ lebih berada di perkotaan tahun 2025 (BPS, 2015). Oleh karenanya, program transmigrasi tetaplah relevan dan diperlukan dilakukan dengan program khusus dan komprehensif.

Program transmigrasi yang dapat menjadi potensi menyelesaikan berbagai masalah tersebut adalah transmigrasi yang ditujukan kepada masyarakat asli atau transmigrasi lokal. Hayashida (2006) mengatakan bahwa dalam konteks pembangunan regional, migrasi dapat menumbuhkan sinergi antara transmigran dan penduduk lokal dalam aktifitas ekonomi. Transmigrasi tersebut bertujuan untuk melatih masyarakat, yang memiliki latar belakang budaya yang sama dengan masyarakat daerah tujuan transmigrasi, dalam pertanian atau perikanan untuk ditempatkan di daerah tertentu. Kesamaan identitas akan memudahkan terjadinya transfer pengetahuan dan teknologi dalam meningkatkan kemampuan sistem pertanian atau kegiatan ekonomi lainnya.

Ketimpangan persebaran penduduk yang dijelaskan sebelumnya juga menjadi alasan terjadinya ketidakmerataan kinerja ekonomi di Daerah Istimewa Yoygakarta (lihat Tabel 2.). Hal tersebut juga menjadi penyebab tingginya urbanisasi yang terjadi dari empat kabupaten ke pusat Kota Yogyakarta. Daerah Istimewa Yogyakarta (DIY) merupakan provinsi dengan tingkat perkembangan yang baik dilihat dari segi pembangunan manusia dan pembangunan fisiknya. Meskipun demikian tetap saja ada "kue pembangunan" tidak terbagi secara merata. Penduduk miskin dan rentan ekonomi masih terlalu banyak di DIY sehingga inisitif untuk mencari kehidupan yang lebih baik tetap dilakukan terlebih bagi mereka yang termasuk kategori miskin dan rentan secara ekonomi. Inisitif yang dilakukan antara lain dengan melakukan transmigrasi ke daerah lain yang dianggap menjanjikan. Bahkan jika dilihat bedasarkan jumlah animo calon transmigran, jumlahnya tergolong besar. Pada 2015 jumlah animo calon transmigran di DIY sebesar 1.240 jiwa. Dari jumlah tersebut 859 jiwa (hampir 70 persen) berniat untuk mendaftar sebagai calon transmigran yang siap diberangkatkan (Disnakertrans DIY, 2015).

Tabel 2. Kepadatan Penduduk menurut Kabupaten/Kota di D.I. Yogyakarta, 2011-2015

Kepadatan Penduduk menurut Kabupaten/ Kota di D.I. Yogyakarta, 2011- 2015/ The Population Density by Regency/City in D.I. Yogyakarta, 2011- 2015

\begin{tabular}{|c|c|c|c|c|c|c|}
\hline \multirow{2}{*}{$\begin{array}{c}\text { Kabupaten/Kota I } \\
\text { Regency/City }\end{array}$} & \multirow{2}{*}{$\begin{array}{c}\text { Luas/ Area } \\
\text { (Km2) }\end{array}$} & \multicolumn{5}{|c|}{ Kepadatan Penduduk/ The Population Density (Jwwa/km2) } \\
\hline & & 2011 & 2012 & 2013 & 2014 & 2015 \\
\hline 1. Kulonprogo & 586,27 & 672 & 680 & 688 & 695 & 703 \\
\hline 2. Bantul & 506,85 & 1819 & 1844 & 1869 & 1893 & 1917 \\
\hline 3.Gunungkidul & 1485,36 & 461 & 466 & 471 & 477 & 482 \\
\hline 4. Sleman & 574,82 & 1942 & 1964 & 1986 & 2008 & 2031 \\
\hline 5. Yogyakarta & 32,5 & 12077 & 12234 & 12390 & 12544 & 12699 \\
\hline DIY & 3185,80 & 1102 & 1115 & 1128 & 1142 & 1155 \\
\hline
\end{tabular}

Sumber: BPS DIY (2015)

Daerah potensial dapat dikembangkan untuk menjadi kawasan transmigrasi adalah daerah yang berstatus lahan Sultan Ground (SG) dan Pakualaman Ground (PAG). Tanah ini dalam PP No. 3 Tahun 2014 termasuk tanah adat yang dapat dijadikan sebagai kawasan transmigrasi setelah diahului pelepasan oleh masyarakat adat (dalam hal ini adalah keraton). Selama ini tanah SG dan PAG banyak dimanfaatkan tanpa seijin dari Panitikismo (lembaga pertanahan Keraton) atau dari otoritas lain. Banyak bukti menunjukkan hubungan negatif antara migrasi dan lingkungan (Siera, 2000; Sunderlin and Resosudarmo, 2001; Worlbank, 2012), dalam hal ini pemanfaatan tanah SG dan PAG yang tidak terkontrol dan cenderung merusak lingkungan dan perencanaan tata ruang.

\section{METODE}

Penelitian ini menggunakan metode kualitatif dan kuantitatif. Penlitian fokus di lahan-lahan yang berstatus sebagai Sultan Ground (SG) dan Pakualaman Ground (PAG) yang berpotensi untuk dijadikan sebagai wilayah transmigrasi. Berdasarkan eksistensi populasinya, penelitian ini menggunakan metode sampling. Untuk memperkuat analisis kualitatif dilakukan wawancara terhadap informan. Informan dalam penelitian ini adalah pihak-pihak yang dianggap dapat memberikan informasi seperti kepala desa dan lembaga pemerintahan lainnya.

Penentuan lokasi desa yang akan digunakan sebagai kawasan transmigrasi dilakukan secara bertingkat berdasarkan administrasi daerah (multistage area sampling). Lokasi sebagai bagian dari unit analisis yaitu 
desa, ditentukan melalui metode berjenjang penentuan sampling dari tingkat Provinsi, kemudian Kabupaten/Kota, kecamatan dan desa atau kelurahan. Kawasan tersebut harus memenuhi kriteria 2C (Clean and Clear) dan 4L (Layak huni, Layak Usaha, Layak berkembang dan Layak lingkungan) dan berbasis partisipasi masyarakat (Gambar 1).

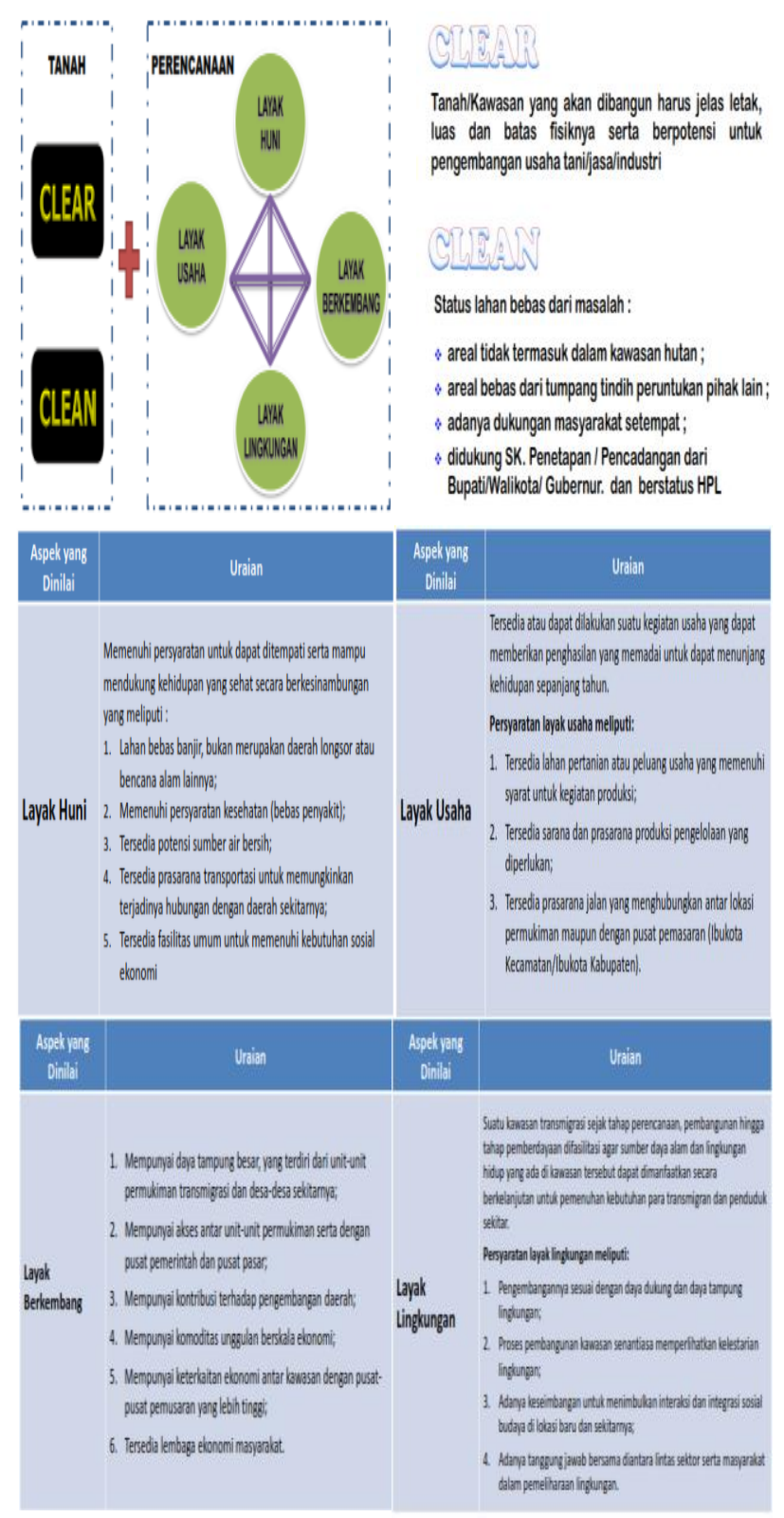

Gambar 1. Syarat Teknis Pembangunan Permukiman Transmigrasi

Indikator atau variabel terkait tersebut kemudian dijadikan dasar bagi penyusunan indikator komposit dalam menentukan lokasi potensial kawasan transmigrasi. Penelitian ini mengembangkan indikator yang digunakan menentukan kelayakan lokasi wilayah pengarahan transmigrasi, sebagai berikut:

1. Indeks Jumlah Penduduk

2. Indeks Kepadatan Penduduk
3. Indeks Status Lahan

4. Indeks Ketersediaan Air

5. Indeks Potensi Sarana Prasarana Umum

6. Indeks Lahan Pertanian

7. Indeks Potensi Komoditas Unggulan

8. Indeks Kerawanan Bencana

Data yang dikumpulkan dari survey dengan kuesioner selanjutnya dikoreksi manual untuk mengecek kelengkapan isian. Apabila semua pertanyaan di kuesioner telah terisi secara benar, langkah berikutnya adalah entri data, koding dan analisis menggunakan SPSS dan Stata (Statacorp, 2001). Data yang telah terkumpul akan dianalisis secara kuantitatif. Tahap analisis dilakukan melalui proses telaah data (thinking process) dan penampilan. Proses telaah data adalah penjelasan atau pengkajian informasi logis dari data yang telah terkumpul seperti melihat pola-pola dan kecenderungan data, membuat hubungan logis dan temuan-temuan umum tentang fenomena yang sedang dikaji (Huberman \& Miles, 1992). Pada proses penampilan data (process of displaying data), informasi-informasi logis dan sejenis yang telah dikelompokkan menurut isu-isu tertentu ditampilkan melalui peta, tabel, diagram, dan gambar. Secara operasional, tahap pengumpulan, pengolahan, dan analisis data secara terperinci adalah sebagai berikut.

1. Tahap penentuan lokasi penelitian dilakukan dengan membuat indeks komposit berdasarkan variabel terkait yang tersedia dari data Podes dan data sekunder lain.

2. Pengumpulan data dilakukan dengan menggunakan kuesioner.

3. Data yang dikumpulkan dan diolah dengan software Stata dan SPSS.

4. Melakukan analisis terhadap variabel-variabel terkait dengan sasaran pengarahan transmigrasi baik melalui tabel frekuensi, tabel silang, dan peta tematik

5. Penyusunan rencana strategis dalam bentuk rekomendasi arahan prioritas potensi wilayah pengarahan transmigrasi.

\section{HASIL DAN PEMBAHASAN}

\section{Menakar Potensi Daerah di Wilayah Tujuan Transmigrasi Lokal}

Penelitian ini melakukan identifikasi terhadap potensi dan penggunaan lahan yang digunakan untuk transmigrasi lokal yang bersatatus sebagai Sultan Ground (SG) dan Pakualaman Ground (PAG). Sultan Ground (SG) dan Pakualaman Ground PAG) yang terletak di Provinsi Daerah Istimewa Yogyakarta sampai saat ini masih diakui, baik oleh pemerintah maupun masyarakat. Sultan Ground dan Pakualaman Ground merupakan tanah hak ulayat Keraton dan Pakualaman yang tersebar di 
seluruh wilayah DIY. Tanah tersebut tersebar secara sporadis tersebar di 4 (empat) kabupaten dan Kota Yogyakarta. Penelitian ini fokus pada SG dan PAG yang terletak di tiga Kabupaten, yaitu Kabupaten Gunung Kidul, Kabupaten Bantul dan Kabupaten Kulon Progo. SG paling luas diperkirakan berada di Kabupaten Bantul yakni 16,7 juta meter persegi, di Kabupaten Kulonprogo 10,3 juta meter persegi dan di Gunungkidul yaitu di hutan jati Kecamatan Playen.

\section{Kabupaten Gunung Kidul}

Kondisi alam di Kabupaten Gunungkidul berbukit-bukit (karst Gunungsewu) mempengaruhi pola permukiman penduduk yang cenderung memusat dan berkelompok (aglomerated rural settlement), meliputi 18 kecamatan dan 144 desa/kelurahan. Permukiman penduduk di Kabupaten Gunungkidul hampir semua merupakan permukiman perdesaan kecuali yang berada di Kecamatan Wonosari, Semanu, dan Playen. Jumlah penduduk Kabupaten Gunungkidul sebesar 683.735 jiwa pada tahun 2013, dengan kepadatan penduduk 460 jiwa per km2 (BPS, 2014). Kecamatan dengan jumlah penduduk terbanyak dan kepadatan tertinggi adalah Wonosari dengan 79.730 jiwa dengan kepadatan 1.056 jiwa/km2. Berdasarkan perbandingan menurut lima lapangan usaha utama, pilihan bekerja di pertanian masih mendominasi pasar kerja di Gunungkidul yakni sebanyak 54,41 persen dan sektor perdagangan, hotel dan restoran 15,70 persen. Sementara pekerja di industri pengolahan sebanyak 8,56 persen; jasa-jasa 12,31 persen dan lainnya (pertambangan dan penggalian, air bersih, listrik, bangunan, transportasi dan perbankan sebesar 9,02 persen). Distribusi PDRB Kabupaten Gunungkidul 2013 tetap didominasi sektor pertanian sebesar 33,29 persen, juga menjadi ciri khas perekonomian Kabupaten Gunungkidul disusul oleh sektor jasa-jasa dan sektor perdagangan, hotel dan restoran (BPS, 2014). Kabupaten Gunung Kidul lima tahun terakhir meningkatkan pembangunan pariwisata berbasis alam khususnya pantai.

Tanah Sultan Ground (SG) di Kabupaten di Gunungkidul teridentifikasi tersebar di 14 kecamatan. Tanah berstatus SG tersebut antara lain tersebar di Kecamatan Semin, Kecamatan Ngawen, Kecamatan Saptosari, Kecamatan Semanu, Kecamatan Nglipar, Kecamatan Rongkop, Kecamatan Patuk, Kecamatan Paliyan, Kecamatan Tepus, Kecamatan Karangmojo, Kecamatan Ponjong, Kecamatan Gedangsari, Kecamatan Wonosari dan Kecamatan Panggang. Jumlah lokasi SG di Kabupaten Gunungkidul seluruhnya berjumlah 1.811 titik. Berdasarkan peruntukan lahannya, lokasi tersebut diperuntukkan untuk tanah kas desa, hutan lindung, kuburan, lapangan, petilasan, pesanggrahan dan tanah tanah kosong yang belum dimanfaatkan. Jumlah lokasi terbanyak SG berada di Kecamatan Wonosari dengan jumlah sebesar 222 titik. Sedangkan jumlah lokasi terkecil untuk tanah status SG berada di Kecamatan Tepus dengan jumlah sebesar 80 titik. Berdasarkan sebaran desanya, Kecamatan Wonosari menjadi penyumbang jumlah lokasi SG tertinggi di Kabupaten Gunungkidul dengan jumlah sebesar 14 desa. Jumlah penyumbang lokasi SG berdasarkan desa terbanyak berikutnya adalah Kecamatan Ponjong dan Kecamatan Patuk dengan jumlah sebesar 11 desa. Sedangkan Kecamatan Semanu menjadi penyumbang paling rendah untuk lokasi SG. Berdasarkan kepemilikan lahan status SG, tercatat hanya 5 desa yang memiliki tanah dengan status SG di Kecamatan Semanu.

Tanah SG yang memiliki potensi untuk dikembangkangkan untuk lokasi transmigrasi lokal di Kabupaten Gunungkidul terdapat di hutan-hutan jati yang tersebar di banyak lokasi. Hal ini terjadi jika dilihat dari segi luas, ketersediaan air yang memadai, penduduk yang masih jarang, dekatnya dengan sarana prasarana umum, serta minimnya ancaman bencana. Akan tetapi status lahan SG di kecamatan-kecamatan tersebut adalah hutan yang dilindungi. Hal ini yang menjadikan nilai potensi luas, ketersediaan air yang memadai, penduduk yang masih jarang, dekatnya dengan sarana prasarana umum, serta minimnya ancaman bencana menjadi tidak diperhitungkan. Selain digunakan sebagai fasilitas umum seperti lapangan, pasar, kuburan atau tanah kas desa, tanah SG telah dimanfaatkan penduduk lokal untuk kegiatan pertanian dan perkebunan. Tanah SG di Kabupaten Gunungkidul banyak dimanfaatkan penduduk untuk perkebunan jati dan perkebunan untuk palawija seperti singkong dan kacang. Tanah yang dikelola oleh masyarakat ini telah diwariskan turun-temurun sehingga seakan-akan tanah tersebut telah menjadi milik mereka padahal sebenarnya statusnya adalah tanah SG. Kondisi ini menjadikan permasalahan di kemudian hari jika lahan SG akan digunakan untuk kepentingan lain, terutama transmigrasi.

\section{Kabupaten Bantul}

Dilihat bentang alamnya secara makro, wilayah Kabupaten Bantul terdiri dari daerah dataran yang terletak pada bagian tengah dan daerah perbukitan yang terletak pada bagian timur dan barat, serta kawasan pantai di sebelah selatan, secara administratif terdiri dari 17 kecamatan yang dibagi menjadi 75 desa. Secara umum jumlah desa yang termasuk dalam wilayah perkotaan sebanyak 41 desa, sedangkan desa yang termasuk dalam wilayah perdesaan sebanyak 34 desa. Jumlah penduduk Kabupaten bantul sebesar 911.503 juwa, dengan penyebaran penduduk yang tidak merata, daerah yang mempunyai kepadatan penduduk geografis tinggi terletak 
di wilayah Kabupaten Bantul yang berbatasan dengan kota Yogyakarta yang meliputi kecamatan Banguntapan (4.383 jiwa $/ \mathrm{km}^{2}$ ), Sewon (3.937 jiwa/ $\mathrm{km}^{2}$ ), dan Kasihan (3.533 jiwa $\left./ \mathrm{km}^{2}\right)$, sedangkan kepadatan penduduk geografis terendah terletak di Kecamatan Dlingo (641 jiwa $/ \mathrm{km}^{2}$ ). Lapangan kerja penduduk Kabupaten Bantul masih didominasi oleh pertanian sebanyak 156.932 atau $36 \%$. Lapangan kerja yang cukup banyak digeluti oleh penduduk Kabupaten Bantul 14\% sektor perdagangan, hotel dan restoran, serta jasa lainnya $15 \%$ seperti kerajinan atau UMKM lainnya. Pada tahun 2013, tiga besar sektor penyusun perekonomian bantul secara berturut-turut yaitu sektor pertanian (19,32 persen); sektor industri pengolahan (19,06 persen); dan sektor perdagangan, hotel, dan restoran (18,55 persen) (BPS, 2014).

Lokasi Sultan Ground di Kabupaten Bantul teridentifikasi di 14 kecamatan. Jumlah total Sultan Ground tersebar 2434 titik menjadikan Kabupaten Bantul wilayah transmigrasi lokal yang potensial. Jumlah titik yang tersebar setiap kecamatan memiliki perbedaan yang cukup signifikan. Persebaran titik Sultan Ground terbanyak di Kecamatan Imogiri sejumlah 372 titik, dan paling sedikit di Kecamatan Pundong sejumlah 80 titik. Kecamatan dengan lokasi Sultan Ground terbanyak berdasarkan desa berada di Kecamatan Imogiri sebanyak tujuh desa, dan yang paling sedikit dua desa di Kecamatan Pundong, Saden, Piyungan, Pandak, dan Sradakan. Banyak daerah, misalnya di Kecamatan Imogiri tanah Sultan Ground tidak dikelola dengan baik, atau hanya dikelola oleh sebagian kecil warga. Bila dicermati lebih mendalam Sultan Ground lebih banyak digunakan untuk fasilitas publik, seperti: kantor pemerintah, makam, tanah kas desa dan lain sebagainya.

Berdasarkan kondisi lahan di Kabupaten Bantul terdapat luas lahan 506,85 Km2 yang terbagi dalam beberapa klasifikasi penggunaan lahan yang terdiri dari pekarangan, sawah, tegal, dan kebun campur. Hal ini juga menjadi potensi karena variasi penggunaan lahan nantinya akan dapat disesuaikan dengan kemampuan calon trasmigran. Penggunaan lahan di Kabupaten Bantul lahan terbesar adalah untuk kebun campur sebesar $32,75 \%$ dan sawah sebesar 31,33\%, sedangkan yang terkecil adalah tambak sebesar $0,06 \%$. Pemanfaatan lahan sebagai kebun campur terbesar terdapat di Kecamatan Pajangan yaitu seluas 2.295,00 Ha. Sedangkan persawahan terluas terdapat di Kecamatan Sewon dengan luas 1.398,26 Ha. Potensi besar daerah pesisir selatan sebagai tambah masih sporadis, yang terbesar di wilayah Kecamatan Srandakan.

Potensi terbesar untuk wilayah transmigrasi berada di wilayah selatan di Kabupaten Bantul. Potensi tersebut berupa lahan yang dapat digunakan sebagai lahan pertanian. Saat ini kawasan dipesisir selatan (di Kecamatan Sradakan, Kretk dan Sradan) sudah mulai banyak warga yang dapat memanfaatkan sebagai lahan pertanian. Selain itu penggunaan lahan juga dapat dilakukan dengan usaha tambak udang atau hasil laut lainnya. Potensi Kecamatan Imogiri sebagai daerah dengan jumlah Sultan Ground terbanyak di Kabupaten Bantul juga layak menjadi lokasi transmigrasi. Penggunaan lahan di Kecamatan Imogiri sebesa 2.128 masih berupa tegalan, 1.186 kebun camuran dan 1.095 lain-lain. Misalnya, di Desa Selopamioro dengan 170 titik Sultan Ground belum terkelola dengan baik. Banyak tanah Sulan Ground dikelola oleh segelintir orang. Contohnya, satu orang warga dapat mengelola 2 hektare tanah Sultan Ground baik sebagai sawah atau tanaman lainnya. Di Desa Selopamioro, kini tercatat sebanyak 548 hektare tanah SG serta seluas 2.275 tanah desa yang terdiri dari tanah kas desa, plungguh dan pengarem-arem. Sebagian besar tanah SG merupakan tegalan dan digunakan warga untuk bercocok tanam. Tanah-tanah tersebut hingga kini banyak dikelola oleh pamong desa, yang banyak diantaranya cenderung dimanfaatkan negatif tanpa mendapatkan perijinan dari lembaga Panitikismo (lembaga pertanahan Kraton).

\section{Kabupaten Kulonprogo}

Kabupaten Kulon Progo memiliki topografi yang bervariasi dengan ketinggian antara 0 - 1000 meter di atas permukaan air laut (dpal), yang terbagi menjadi 3 wilayah meliputi: bagian Utara merupakan daratan tinggi/perbukitan Menoreh, bagian Tengah merupakan daerah perbukitan, bagian Selatan merupakan dataran rendah termasuk pesisir. Secara administratif terbagi menjadi 12 kecamatan yang meliputi 87 desa, 1 kelurahan, dan 918 pedukuhan, Kecamatan Wates menjadi wilayah terpadat $1.429 \mathrm{jiwa} / \mathrm{km}^{2}$ dan Kecamatan Samigaluh merupakan wilayah yang kepadatannya paling rendah yaitu sebesar $366 \mathrm{jiwa} / \mathrm{km}^{2}$. Sebagian besar penduduk bekerja pada sektor pertanian sebanyak 50,17 persen, sektor perdagangan, hotel dan restoran sebesar 17,84 persen, sebanyak 11,64 persen bekerja pada sektor industri, 12,17 persen bekerja pada sektor jasa lainnya dan sektor lembaga keuangan dan sektor jasa-jasa persentasenya kurang dari 10 persen. Struktur perekonomian Kulon Progo pada tahun 2013 menunjukkan bahwa sektor pertanian, sektor jasa-jasa, serta sektor perdagangan, hotel, \& restoran masih merupakan leading sector bagi perekonomian di Kulon Progo. Artinya bahwa ketiga sektor tersebut masih menjadi sektor yang dominan di Kabupaten Kulon Progo. Sektor pertanian memegang kontribusi sebesar 22,87 persen, sektor jasa-jasa 22,64 persen, dan sektor perdagangan, hotel \& restoran sebesar 17,27 persen. 
Informasi mengenai status tanah SG atau PA Ground sangat terbatas di Kabupaten Kulon Progo. Berdasarkan hasil wawancara staf Provinsi DIY mengatakan bahwa pendataan jumlah lokasi tanah SG dan PAG belum selesai dilakukan (hingga penelitian berakhir). Hasil observasi dan wawancara yang dilakukan, Tanah SG dan PAG yang terdapat di Kabupaten Kulon Progo secara umum bersifat fragmented (terpecah-pecah) di hampir seluruh kecamatan. Hal ini seperti keadaan SG di Kabupaten Gunungkidul dan Bantul dimana lokasinya tersebar dengan berbagai peruntukan lahan. Tidak semua SG atau PAG dapat dikembangkan untuk kawasan transmigrasi. Tanah SG dan PAG yang terdapat di Kabupaten Kulon Progo yang potensial untuk dikembangkan untuk kawasan transmigrasi teridentifikasi antara lain terdapat di empat kecamatan, Kecamatan Panjatan, Kecamatan Galur, Kecamatan Wates, dan Kecamatan Temon.

Penetapan empat lokasi tersebut sebelumnya didasarkan pada pertimbangan potensi luas, ketersediaan air yang memadai, penduduk yang masih jarang, dekatnya dengan sarana prasarana umum, serta minimnya ancaman bencana. Wilayah potensial yang mampu dikembangkan untuk wilayah transmigrasi lokal di DIY terdapat di empat kecamatan yang terletak di sepanjang daerah yang berbatasan dengan pantai selatan DIY. Tanah Pakualaman Ground yang teridentifikasi dapat digunakan sebagai daerah transmigrasi adalah tanah yang termasuk dalam wilayah desa-desa yang berbatasan langsung dengan Pantai Selatan. Lahan SG dan PAG di Kabupaten Kulon Progo dalam beberapa tahun terakhir dimanfaatkan penduduk untuk membangun permukiman. Status permukiman tersebut sebenarnya adalah permukiman yang tidak berijin atau sering disebut permukiman liar. Akan tetapi dikarenakan penduduk tersebut telah lama menempati lokasi tersebut dalam waktu yang lama, maka timbul perasaan bahwa tanah tersebut seolah-olah telah menjadi hak milik. Lahan SG dan PAG tersebut di beberapa tempat telah dialihfungsikan penduduk sekitar untuk membuat perladangan, persawahan bahkan pertambakan.

\section{Tantangan Program Transmigrasi Lokal di DIY}

Kondisi wilayah tujuan transmigrasi yang dijelaskan sebelumnya menunjukkan bahwa pengukuran terhadap indeks penentuan wilayah transmigrasi di tiga kabupaten di DIY dapat dikatakan cukup layak. Potensi tersebut bervariasi mulai dari pertanian, perkebunan hingga budidaya perikanan sesuai dengan topografi DIY. Terlebih lagi posisi DIY sebagai daerah tujuan pariwisata nasional dan internasional menjadikan potensi tersebut dapat dikelola dengan banyak cara. Namun, bila dicermati lebih mendalam, terdapat berbagai masalah mendasar yang harus terselesaikan terlebih dahulu sebelum program transmigrasi dilakukan. Masalah tersebut setidaknya terbagi dalam tiga hal, yaitu kondisi lahan SG dan PAG, penerimaan penduduk lokal terhadap pendatang, dan kapasitas transmigran dalam mengelola berbagai variasi potensi yang banyak diantaranya tidak dimiliki.

\section{Kondisi Lahan}

Lahan potensial sebagai tujuan transmigrasi diberbagai titik telah beralih fungsi menjadi beragam bentuk pemanfaatan. Seperti yang dijelaskan sebelumnya, banyak diantaranya dimanfaatkan sebagai pemukiman, persawahan, perladangan, kebun, tambak dan bahkan dipetakan masuk sebagai hutan lindung. Sebagian besar tanah SG merupakan tegalan dan digunakan warga untuk bercocok tanam. Tanah-tanah tersebut hingga kini banyak dikelola oleh pamong desa, yang banyak diantaranya cenderung dimanfaatkan negatif tanpa mendapatkan perijinan dari lembaga Panitikismo (lembaga pertanahan Kraton).

Pemanfaatan lahan di pesisir selatan juga menjadi masalah besar tidak terselesaikan terkait tidak adanya peraturan dan tanpa ijin. Pemanfaatan pesisir selatan banyak diantaranya sebagai tambak udang liar yang menyebabkan banyak kerusakan. Bahkan, berdasarkan wawancara mendalam dengan penduduk di pantai selatan Kabupaten Bantul, penduduk tidak hanya menjadikan tambak sebagai usaha sendiri, namun mereka juga membukakan lahan bagi "investor" yang ingin terlibat dalam pemanfaatan kawasan pantai sebagai tambak.

Tanah tersebut adalah milik Sultan atau Pakualaman yang di dalam Undang-Undang dikategorikan sebagai tanah adat atau tanah ulayat. Permasalahan baru akan muncul apabila rencana lokasi transmigrasi bersentuhan dengan lahan yang selama ini dimanfaatkan penduduk untuk permukiman dan kegiatan ekonomi tersebut. Secara otomatis mereka akan mengklaim bahwa tanah tersebut adalah dalam "kepemilikan" mereka dan tentu saja untuk memindahkan mereka akan dibutuhkan cost yang tidak sedikit. Rasa memiliki yang dimiliki oleh penduduk yang telah menggarap lahan tersebut selama bertahun-tahun akan menghambat rencana lokasi penempatan transmigrasi dan berpotensi besar akan menimbulkan konflik. Meskipun demikian, berdasarkan penuturan masyarakat di beberapa desa yang masyarakatnya memanfaatkan lahan SG dan PAG sebagai lokasi tempat tinggal namun tidak memiliki sertifikat lahan, siap menyerahkan apabila lahan tersebut akan digunakan untuk suatu kepentingan.

"Masyarakat disini nyaman tinggal di tanah

Sultan karena kami yakin bahwa Sri Sultan tidak akan mengambil kembali tanahnya, tapi 
kalau sultan mau mengambil kembali tanahnya kami siap kapanpun" (Wawancara Oktober 2015)

\section{Penerimaan Penduduk Lokal terhadap Pendatang}

Penerimaan penduduk lokal terhadap pendatang menjadi permasalah yang jamak dijumpai diberbagai lokasi transmigrasi. Tidak hanya itu, berbagai konflik diberbagai daerah terjadi akibat transmigrasi yang melupakan tinjauan mengenai penerimaan penduduk lokal terhadap pendatang, terutama dalam transmigrasi pendatang dalam jumlah besar (Hoey, 2003). Masyarakat lokal, selain tidak memiliki hak tanah seperti yang diberikan oleh negara terhadap transmigran, banyak diantaranya merasa terancam dengan kedatangan pendatang dalam hal ekonomi, skill dan pendidikan (Kesaulija, 2014).

Pemetaan yang dilakukan di tiga kabupaten di DIY menemukan bahwa masyarakat belum memiliki pengalaman dengan perpindahan penduduk dalam jumlah besar. Hal ini mengingat desa-desa di DIY bagian selatan memiliki penduduk yang homogen dan secara turuntemurun menempati wilayah tersebut. Hampir diseluruh desa yang menjadi lokasi penelitian menunjukkan bahwa perpindahan penduduk yang pernah terjadi dalam sekala kecil, biasanya merupakan hasil pernikahan warga lokal dengan warga dari luar wilayah tersebut. Di daerah pesisir, yang memiliki potensi besar terutama bidang perikanan dan pariwisata, penduduk dari luar daerah yang ingin membangun rumah di lahan SG secara permanen tidak dapat dilakukan karena menimbulkan penolakan.

"Penduduk pendatang tidak boleh mengolah tanah sultan, itulah kesepakatan penduduk dusun sejak dulu" (Wawancara November 2016 dengan berbagai tokoh desa di pesisir selatan Kabupaten Bantul)

Program transmigrasi lokal yang diusulkan dalam penelitian ini sebenarnya memiliki potensi terjadinya konflik yang lebih rendah dibandingkan dengan transmigrasi antara provinsi atau pulau. Pandangan penduduk terhadap pendatang yang berpotensi menjadi pesaing dalam bidang sosial ekonomi dapat dirubah dengan komunikasi kebijakan yang tepat sasaran. Terlebih lagi, mayoritas pendaftar program transmigrasi yang terdata oleh DISNAKER DIY merupakan penduduk asli DIY dengan kesamaan atas latar belakang nilai, norma, budaya dan kepercayaan. Hal ini akan mendukung percepatan terwujudnya kohesi sosial yang kuat diantara penduduk lokal dan pendatang.

\section{Kapasitas Transmigran}

Kapasitas transmigran dan penduduk lokal harus dipehatikan dalam mencapai tujuan pembangunan (Kesaulija, 2014). Kemajuan pesat dalam pembangunan pariwisata DIY turut serta membawa perubahan sosial terhadap masyarakat, khususnya pekerjaan. Masyarakat agraris yang telah melekat sebagai identitas masyarakat DIY telah berubah seiring rentang variasi pekerjaan yang semakin luas. Penduduk DIY saat ini lebih banyak yang memiliki pekerjaan di sektor jasa dan UMKM khususnya kerajinan. Tentu hal ini menjadi tantangan besar merubah masyarakat untuk beralih ke sektor agraris yang menjadi potensi daerah tujuan transmigrasi.

Lokasi pesisir selatan yang dekat dengan laut, sektor usaha yang akan dikembangkan optimal adalah sektor perikanan, pariwisata dan sebagian kecil untuk usaha pertanian lahan kering. Persiapan calon transmigran di wilayah tersebut juga menuntut adanya kemampuan menjadi nelayan sebagai konsekuensi apabila lahan tidak bisa dimanfaatkan sebagai lahan pertanian atau tambak udang. Pertanyaan besar yang nanti akan muncul adalah apakah para calon transmigran memiliki keahlian dalam sektor perikanan? Jika tidak maka solusi yang ditawarkan adalah sosialisasi dan pemberian pelatihan dalam sektor perikanan. Sedangkan jika calon transmigran sudah memiliki kemampuan dalam bidang perikanan maka pendampingan dan pelatihan lanjut perlu dilakukan. Intinya adalah menghindari kemungkinan calon transmigran tidak memiliki pengetahuan sedikitpun tentang daerah yang akan dituju dan potensi sumberdaya yang ada.

\section{PENUTUP}

\section{Simpulan}

Transmigrasi telah dipraktekkan di indonesia sejak pemerintahan kolonial belanda. Tranmigrasi selama ini dianggap tidak optimal karena menempatkan transmigran dan masyarakat lokal pada kompetisi yang tidak seimbang. Transmigrasi yang seharusnya menjadi alat tranfer pengetahuan dan teknologi dalam mengembangkan potensi lokal, justru menimbulkan banyak masalah hingga berujung konflik. Gagasan transmigrasi lokal yang berusaha dikembangkan dalam penelitian ini menunjukkan transmigrasi lokal berpotensi dilakukan di DIY. Identifikasi potensi lokasi tujuan transmigrasi, yaitu di lahan SA dan PAG, menunjukkan potensi pemanfaatan yang bervariasi. Potensi pemanfaatannya meliputi pertanian, pekebunan, dan perikanan. Potensi terbesar terdapat di daerah pesisir selatan dimana transmigan dapat memanfaatkannya sebagai pertanian lahan kering atau perikanan. Namun, data lahan SA dan PAG yang belum lengkap, banyak yang telah mengalihfungsikan lahan-lahan tersebut menjadi pemukiman, persawahan bahkan tambak. Beberapa tantangan dalam mewujudkan kebijaka transmigrasi lokal terkait kondisi lahan yang telah dimanfaatkan 
penduduk setempat tanpa ijin, penerimaan masyarakat terhadap pendatang, dan peningkatan kapasitas transmigran. Untuk mengatasi tantanagn tersebut, pemerintah dapat melakukan beberapa hal diantaranya:

1. Pemetaan penggunaan lahan secara menyeluruh dan mulai negosiasi dengan masyarakat lokal terkait pemanfaatan menjadi lahan produktif.

2. Pemerintah harus secara persuasif berkomunikasi dengan masyarakat lokal terkait kebijakan transmigrasi dan upaya percepatan integrasi sosial antara transmigran dengan penduduk lokal.

3. Peningkatan kapasitas calon transmigran harus dilakukan secara berkelanjutan jauh sebelum transmigran dikirim ke daerah tujuan..

\section{DAFTAR PUSTAKA}

Adhiati, M dan Bobsien, A. 2001. An Update: A Report Prepared for Down to Earth. International Campaign for Ecological Justice in Indonesia [http://www.downtoearth-indonesia.org].

Hayashida. 2006. Transmigration Policy and Regional Development in Indonesia. Journal of The Social Sciences. 23-47.

Hoey, B., A. 2003. Nationalism in Indonesia: Building Imagined and Intentional Communities Trough Transmigration. Ethnology, 109-26.

Hugo, G. 2006. Forced Migration in Indonesia: Historical Perspectives. Jurnal Asia and Pacific Migration. 53-92

Kesaulija, F., et. al. 2014. Oil palm estate development and its impact on forests and local communities in West Papua. Working Paper 156, Center for International Foresty Research.
Levang, P. et. al. 1999. Not Every Cloud Has A Silver Lining: Crop Farmers in Transmigration Areas. ACIAR Indonesian research project. Working paper. 99: 16.

Miles, B. B dan Huberman, A. M. 1992. Analisa Data Kualitatif. Jakarta: UI Press

Nitiyasa, I. G dan Sudibia, I. K. 2013. Menggalakkan Program Transmigrasi Melalui Peningkatan Pembangunan Daerah. PIRAMIDA: 50- 56

Nugroho, A. S. 2013. Evaluation of Transmigration (Transmigrasi) In Indonesia: Changes In Socioeconomic Status, Community Health and Environmental Qualities of Two Specific Migrant Populations. Desertasi Kagoshima University.

Pona, La. 2005. Stereotip Etnis Masyarakat Papua Terhadap Transmigran. Makalah seminar Prospek Pembangunan Transmigrasi di Provinsi Papua. Unpublished paper

Sheil, et.al. 2006. Recognizing Local People's Priorities for Tropical Forest Biodiversity. Ambio 35; $17-24$

Sierra, R. 2001. The Role Of Domestic Timber Markets in Tropical Deforestation and Forest Degradation in Ecuador: Implications For Conservation Planning and Policy. Ecological Economics. 327-340

Smith, N. 1981. Colonization Lessons from a Tropical Forest. Science. 755-761.

Sunderlin, W. D. and Resosudarmo I. A. P. 2001. Rate and Causes of Deforestation in Indonesia: Towards a Resolution of the Ambiguities. cifor.org. 